\title{
The use of magnetic fields in treatment of patients with rheumatoid arthritis. Review of the literature
}

\author{
Jolanta Zwolińska ${ }^{1,2}$, Monika Gąsior², Elżbieta Śnieżek ${ }^{1}$, Andrzej Kwolek ${ }^{1}$ \\ ${ }^{1}$ Institute of Physiotherapy, Rzeszów University, Rzeszow, Poland \\ ${ }^{2}$ Regional Rehabilitation-Educational Centre for Children and Teenagers with the name of blessed John Paul II at the Provincial Clinical \\ Hospital No. 2 in Rzeszow, Poland
}

\begin{abstract}
Magnetic fields are commonly used in therapies designed for subjects with rheumatic diseases, yet the effects of magnetotherapy are not entirely clear in these disorders.

This study is designed to examine the literature investigating applications of magnetotherapy in the treatment of rheumatoid arthritis (RA).

The review focused on publications related to administering magnetotherapy in patients with RA. The databases Science Direct, SpringerLink, Medline, PubMed, and Polska Bibliografia Lekarska were searched for reports published since 2005.

Despite the numerous reports showing an impact of magnetic field in subjects with RA, the effectiveness of magnetotherapy has not been explicitly confirmed. Given the above, further research appears to be necessary to clarify the impact of magnetic fields on biological systems, and the relationship between magnetic field intensity and the obtained results as well as their durability. The majority of clinical trials have failed to identify any undesirable outcomes or side effects of this physical therapeutic factor.
\end{abstract}

Key words: rheumatic diseases, magnetotherapy, physical therapy modalities, pain.

\section{Introduction}

Along with the scientific and technical progress and technological development, physical medicine offers new treatment options [1]. Therapy using physical factors requires high standards of safety and experience of a referring doctor and a therapist. Physical therapy may be an important treatment method supplementing medication or rehabilitation [1, 2].

The use of magnetic field (MF) therapy is associated with intensive development of knowledge about the impact of this field on a living organism at the level of cells and tissues [3]. However, contemporary knowledge of the mechanism of the MF impact on living organisms still leaves many uncertainties [4]. The mechanism of therapeutic effects of MF on the system is not fully understood [5]. A thorough analysis of the physical nature of the MF as well as performing objective clinical trials to assess the impact of the field on the system are required to optimize the effects of magnetic therapy $[1,4]$. The need to validate the safety and efficacy of magnetotherapy in the course of various diseases and syndromes stems from the guidelines of evidence-based medicine (EBM) and is a challenge for today's researchers.

\section{Magnetic field and its impact on the organism}

Magnetic energy is everywhere in the world [6]. According to Heisenberg, it is elementary energy, on which the organism's life is dependent [7]. The Earth's magnetic field shows the intensity in the range of 30-70 $\mu \mathrm{T}$, which is a natural stimulator of physiological processes in a living organism [8]. The phenomenon of

Address for correspondence:

Jolanta Zwolińska, Institute of Physiotherapy, Rzeszów University, Warszawska 26A, 35-205 Rzeszow, Poland, e-mail: jolantazwolinska@op.pl Submitted: 17.07.2016; Accepted: 30.08.2016 
increased incidence of various diseases of the human organism is explained by the constant decrease in the strength of the Earth's magnetic field [5, 9]. Observations of people staying in space for a long time indicate that lack of a natural magnetic field causes insomnia, fatigue, and depression, and increases the risk of osteoporosis [10].

The MF causes movement of the ions within the cell, which results in hyperpolarization of the cell membrane. This affects the acceleration of metabolism, especially stimulating the energy processes and increasing the use of oxygen by the cell $[6,10,11]$. Such changes are a stimulant to proliferation or apoptosis processes [12]. The MF has a beneficial effect on the regenerative mechanisms occurring in the tissue and stimulates humoral and immune activity in the whole organism [6, 11]. It enhances hormonal and enzymatic reactions. The MF also acts on bone and connective tissue. Electric currents induced in tissues may affect the piezoelectric properties of materials, causing mechanical deformation, which stimulates the formation of callus in the case of obstruction in bone healing [10]. The application of MF for therapeutic purposes is based on studies which confirmed the anti-inflammatory, antiedematous, vasodilatory and angiogenic action $[6,13]$. Magnetotherapy also has an analgesic effect, affects muscle tension, and stimulates the regeneration of tissues [10, 14-16]. It has a calming effect, affects well-being and has preferable influences on the human psyche $[9,17]$.

Effective application of magnetotherapy requires application of recommended field parameters and adhering to the guidelines of the treatment methodology $[4,18]$. The magnetotherapy treatments require different types of field generators, intensity and course of the field as well as different ways of application [8, 10, 19]. These values are selected individually depending on the patient's general condition and the stage of the disease [8]. The magnetic field allows deep penetration of the tissue due to the penetrating power of the various structures including plaster casts $[11,16]$.

Magnetotherapy can be applied safely for longer series (10-15 treatments or more). Initial treatment is carried out daily, then every other day and the last treatment up to 2 times per week [10]. The analgesic effect of magnetotherapy increases with the number of procedures performed [20]. Fifteen-minute treatments can sometimes be extended to 60 minutes, whereas it is not advisable to use treatments lasting less than 5 minutes [10]. Most treatments recommended last 30 minutes [21]. Treatments in the late evening hours are not recommended [10]. Treatment with a pulsating electromagnetic field (PEMF) is often combined with other physical and balneotherapeutic procedures, which used together improve the therapeutic effect $[5,9,10]$. Substantive preparation of physical therapists to perform procedures as well as compatibility of values declared by a manufacturer with the actual state are factors that determine the therapeutic effects [8].

Treatments using permanent magnets where the magnetic field is generated by a magnet attached to clothing, pillows, jewelry, shoes, etc. are also used within magnetotherapy [22]. Permanent magnets are easy to use, inexpensive and widely available. The use of such magnets is a form of treatment of chronic pain associated with dysfunction of the musculoskeletal system and inflammatory disorders including rheumatoid arthritis (RA) [19]. The current state of knowledge is not sufficient to unambiguously confirm the therapeutic efficacy of static magnetic fields [23]. Not all clinical trials on the action of permanent magnets carried out so far are characterized by high methodological quality, and the results of these tests cannot provide scientific evidence for the effectiveness of such therapy in all cases [19].

\section{Safety of magnetotherapy}

The magnetic field does not cause a thermal effect in the tissue and is not directly sensed by the human body $[10,14,24]$. Greater intensity of this field is reported by the subjects as various kinds of feelings including tingling and vibration [17]. No significant side-effects when using such fields were noted [14]. In the case of hypersensitivity, neurasthenic and vegetative symptoms, dermatological symptoms (redness, tingling, burning), blurred vision, increased sensitivity to chemical stimuli and other symptoms are possible [17]. The International Agency for Research on Cancer classified magnetic fields of low-frequency EMF-LF (low-frequency electromagnetic fields) as a possible carcinogenic factor [18]. Static magnetic fields are considered safe even for very high magnetic induction, whereas the harmful effects of electromagnetic fields on the human body with longterm exposure to them have been proven $[8,12,25]$. It is important to consider the possible risks and compliance with applicable rules for the procedures [8].

\section{Rheumatoid arthritis - impact on efficacy and quality of life}

The incidence of rheumatoid arthritis in the world ranges from 0.3 to $1.5 \%$ of the population, while in Europe it affects $0.8 \%$ of the adult population [26]. It is estimated that in Poland, about 400,000 people suffer from inflammatory diseases of the joints, including 135,000-157,000 suffering from RA. There has been a continuous increase in the number of cases [27]. RA usually affects people aged 30-50 years. Women suffer 
2-3 times more often. Compared with the general population, patients with RA live 7-10 years shorter lives [26, 28]. The economic costs which result from this disease are primarily associated with the loss of ability to work and the need to provide care in the event of loss of efficiency [27].

Rheumatoid arthritis is a chronic and progressive condition. The ongoing inflammatory process leads to distortion of the joints, impairment of their function, complications in the internal organs and mental changes. The disease leads to a significant reduction in the quality of life, disability and premature death [29]. Symptoms of depression occur in 13-25\% of patients with RA when the patient realizes the unfavorable prognosis in this disease [26]. The characteristic clinical features of RA include pain - often chronic - swelling, limitation of movement, stiffness and inflammation occurring in multiple joints $[9,29,30]$. Pain is the most important factor determining the level of disability of the patient [31]. Joint pain causes the muscle tension reflex, which causes compression of the damaged joint structures, and aggravates pain. The mechanism of the so-called vicious circle of pain is formed [14, 32]. The physical activity of the patient is limited, a gradual loss of muscle and bone tissue, disorders of sleep and general fatigue are observed. The patient becomes more dependent on the environment [15, 26, 29].

Treatment of patients with RA is multi-action, involving pharmacological, surgical and rehabilitative approaches. The range of treatment and rehabilitation is dependent on the functional status of the patient, age, disease duration and the extent of damage to the musculoskeletal system [15, 33, 34]. Rehabilitation at each stage slows the progression of the disease process and improves the quality of life of the patients with RA [30, $35,36]$. Laboratory tests make it possible to assess the effectiveness of therapy and its possible modification $[29,37]$. Rehabilitation of the patients with RA is a complex process conducted from the time of diagnosis to the end of life [30].

As a part of comprehensive rehabilitation, physical factors are applied which have an analgesic effect, reduce morning stiffness, improve the functional status of the patient and limit the use of analgesic medication [14, 38, 39]. The first noticeable effects appear after a series of treatments. The quality of the effects is positively affected by the continuation of treatments in the spa (lat sanus per aqua), where there is a possibility to enrich the comprehensive physiotherapy for balneotherapy. Such an approach increases the analgesic effect and extends the response [40]. The therapy with both permanent and extremely low-frequency MF (ELF MF) is successfully applied among the physical treatment methods.

\section{Application of magnetic field in patients with rheumatoid arthritis}

The magnetic field of low frequency (LF-EMF) is commonly used in the treatment of patients with diseases of the osteoarticular system including RA [16, 21]. Both magnetotherapy treatments (induction above 0.1 $\mathrm{mT}$ ) and magnetic stimulation (induction below $0.1 \mathrm{mT}$ ) are used [6]. Therapy reduces the reactivity of the immune system in case of inflammatory and degenerative changes in the joints [10]. It also gives an analgesic and antiedematous effect [3, 40]. According Cieślińska-Świder [14], magnetic intensity of $2 \mathrm{mT}$ and frequency of $12 \mathrm{~Hz}$ are used in arthritis. The recommended treatment time is from 15 to 30 minutes, and the treatments are performed 1-2 times per day for several weeks [14].

The aim of the research carried out by Kumar et al. [41] was to evaluate the effect of pulsed electromagnetic fields (PEMF) on experimentally induced inflammation in rats. A sinusoidal unipolar magnetic field was applied with different parameters. The activity of lysosomal enzymes, inflammatory cell infiltration as well as swelling were assessed. Optimal field parameters were $4 \mathrm{mT}$, $5 \mathrm{~Hz}$ and exposure time of $90 \mathrm{~min}$ in that case [41]. In studies by Dortch and Johnson [42] rats with experimentally induced rheumatoid arthritis were subjected daily to AC magnetic field with the parameters $10 \mathrm{mT}$ and 5-50 Hz. It has been shown that PEMF may be a useful therapeutic agent in the treatment of chronic inflammatory diseases such as rheumatoid arthritis [42].

Shupak et al. [43] conducted a double-blind, randomized trial with a control group including patients with RA and fibromyalgia. The study groups were subjected to magnetotherapy with two different values of the maximum induction of $200 \mu \mathrm{T}$ and $400 \mu \mathrm{T}$. The studies showed a slight decrease in the level of pain after using magnetotherapy, although the change was not statistically significant. The authors concluded that magnetic therapy shows little analgesic effect in patients with RA [43]. The studies by Krawczyk-Wasielewska et al. [28] investigated 50 patients with RA subjected to various types of physiotherapy treatments (cryotherapy, sonotherapy, magnetic field, laser therapy, diadynamic, TENS method). Swelling, pain level and duration of morning stiffness were assessed before and after treatment. There were no urinary symptoms after applying any physicotherapeutic factor. The authors showed that the magnetic field resulted in the reduction of pain in $82 \%$ of the respondents, while the magnitude of the analgesic effect was evaluated by the authors as moderate. There was a decrease in swelling and reduction in the duration of morning stiffness. Cryotherapy, laser therapy, TENS and sonotherapy were considered the most effective by the authors [28]. 
Greaves and Harlow [44] evaluated the usefulness of the application of weak magnets in the observation of placebo effects in the studies on magnetotherapy. They used magnets of $180 \mathrm{mT}$ as active magnets and magnets of $50 \mathrm{mT}$ as a placebo. The authors concluded that the magnets of $50 \mathrm{mT}$ may not be applied in a placebo trial, as in the subjective evaluation of the patients they have a therapeutic effect [44]. The studies by Krawczyk-Wasielewska et al. [33] showed that the use of physical factors in people with rheumatoid arthritis (thermotherapy, sonotherapy, phototherapy, electrotherapy and magnetic therapy) during a two-week hospital stay reduced pain and improved the functional status and the level of overall efficiency in all patients [33]. Kalmus et al. [39] showed that using magnetic mattresses generating strong magnetic field with a maximum induction of $64 \mathrm{mT}$ decreased motor activity during sleep, which contributed to the improvement of its quality. There was a statistically significant reduction in the level of pain as well as a statistically significant reduction in the dosage of NSAIDs in the group treated with magnetotherapy [39].

Skalska-Izdebska et al. [45] confirmed the analgesic and antiedematous effect of magnetotherapy in patients with RA. All 20 subjects who underwent magnetotherapy reported a reduction in periarticular edema and $70 \%$ achieved an analgesic effect [45]. The studies of Walasik et al. [46] evaluated the effectiveness of some sets of physical therapy performed on RA patients' hands on an outpatient basis. The effectiveness of two sets of physiotherapy treatments used in group A (sonotherapy, laser therapy) and group B (magnetic therapy, cryotherapy) was compared. The same kinesiotherapeutic program including manual hand exercises was used in both groups. It was found that applying physical procedures in combination with kinesiotherapy effectively limits the number of tender and swollen joints and reduces pain. It was shown that a set consisting of magnetotherapy and cryotherapy is more effective [46]. Chwieśko-Minarowska et al. [47] compared the effect of laser stimulation and low-frequency magnetic field on the function of the hand and the quality of life of patients with RA. Magnetic field intensity from $3 \mathrm{mT}$ and a frequency of $5 \mathrm{~Hz}$ were used, gradually increasing parameters to $7.5 \mathrm{mT}$ and $23 \mathrm{~Hz}$. In the group treated with laser stimulation, there was a reduction of pain in contrast to treatment with the magnetic field. A reduction in the number of swollen joints and improved quality of life were reported in both groups. Better results were obtained after laser therapy [47]. The studies by Leśniewicz et al. [21] evaluated the effect of treatments on the physical mobility of women with RA. Reduction of pain after using iontophoresis, magnetotherapy as well as joint application of those treatments was obtained.
The results showed no significant differences between the effects of iontophoresis treatments and the effects of iontophoresis treatments supplemented with magnetotherapy [21].

The review by Eccles [48] included 21 studies and assessed their level of methodological quality. Eleven studies of high methodological quality confirmed the positive analgesic effect of permanent magnets on musculoskeletal, neuropathic, inflammatory and rheumatic pain. The author concluded that published controlled clinical trials confirmed the analgesic effect of permanent magnets [48].

The review by Macfarlane et al. [22] included a study conducted on 64 patients with RA divided into two groups. The static magnetic field of $190 \mathrm{mT}$ and $72 \mathrm{mT}$ was compared. A decrease in pain was observed in both groups. In the group treated with a higher value of induction, a significantly greater reduction in disease activity and significantly better results in terms of subjective assessment of the patient of the symptoms' severity was observed. The authors also compared the efficacy of different therapies (acupuncture, meditation, autogenic training, progressive muscle relaxation therapy, static magnetic field and tai chi) in the treatment of patients with RA. The analgesic effectiveness of none of the listed therapies was explicitly confirmed; however, the overall health assessment performed at different time points after application of magnetotherapy improved. No adverse events or side effects were observed in the course of therapy [22].

In summary, the magnetic field is a useful physical factor used in modern and comprehensive rehabilitation implemented in numerous dysfunctions and symptomatic syndromes. Magnetic fields and magnetic stimulation are effective in promoting the treatment of inflammatory diseases and musculoskeletal injuries, diseases of the nervous system, muscle tone disorders, and diseases of the digestive and urogenital system [10].

Rehabilitation of people with rheumatic diseases reduces pain and improves the functions of the musculoskeletal system, while reduction of stress has a positive effect on the psyche of the patient and improves quality of life $[36,49]$. A doctor determines the type and way of conducting the therapy. They should choose a procedure which is the most effective and safe with regard to indications and contraindications in the recent literature of the subject $[1,14,29]$. It is important to conduct a thorough interview with the patient, who may downplay their status or knowingly conceal disturbing symptoms [50]. Reactions to physiotherapy may arise from the nature of the disease, the stage of the disease, locomotor performance, the emotional condition of the patient and the degree of involvement in the treatment process [40]. 
The magnetic field is a natural method of treatment and is considered as an effective physical factor used in patients with RA $[19,28,51]$. Medications often have side effects and can cause addiction, and therefore longterm use may not be well tolerated by the body and sometimes poses a significant risk [11, 19]. The analgesic effect of magnetotherapy can reduce pharmacotherapy [3, 20]. Samborski [9] stresses that the solution is to complement pharmacological treatments with kinesiotherapy and physical treatments. According to the author, it is a mistake to discontinue pharmacotherapy and replace it with physical therapy [9].

Efficacy of physical therapy, including magnetic field therapy, in patients with RA raises doubts in some authors $[17,52]$. Issues related to the influence of LF-EMF on the human body are unresolved in the world of science and require further research [17]. Research on restrictions on the use of the magnetic field, precautions and possible side effects are still needed, as contraindications to the use of a given physical stimulus are often based on assumptions about the possibility of adverse effects, and not on the evidence obtained on the basis of studies of their biological properties [53]. Research of the highest methodological quality requires a control group with a placebo therapy. The lack of sensations during magnetotherapy treatment makes such clinical trials possible. According to Richmond, the difficulty in conducting research of the highest methodological quality with the participation of people with RA is that it is used in subjects who are administered long-term pharmacotherapy and the abandonment of it for the duration of the research projects is a problem of an ethical nature [19]. Some research projects do not take into account the long-term follow-up, and therefore the durability of treatment effects cannot be assessed as well as observation of the possible factors affecting the outcome during short-term follow-up.

\section{Summary}

The continuation of studies on the effects of magnetic fields on biological systems, the effects of therapy on the parameters of the magnetic field and the possibility of obtaining remote therapeutic effects is necessary. The methodology of previously conducted clinical trials should be carefully but also critically analyzed due to the fact that the parameters quoted in the work and the units in which they are expressed sometimes raise doubts. The effects of longer follow-up are particularly important in studies that use questionnaires of disability as well as scales of quality of life. In addition, the inclusion of a group of patients as large and homogeneous as possible in the research will provide clear evidence of the effectiveness of magnetotherapy in the treatment of patients with RA. This requires careful development and dissemination of methodological guidelines concerning the application of the magnetic field, which will provide optimal effects of such therapy.

The authors declare no conflict of interest.

\section{References}

1. Saran T, Maruszewska A, Sokołowski K, et al. Najczęstsze przyczyny kierowania chorych na zabiegi fizykoterapeutyczne. Acta Balneol 2010; 52: 31-36.

2. Bauer A, Wiecheć M. Systematyka zabiegów fizykalnych. Prakt Fizjoter Rehabil 2010; 10: 8-11.

3. Johnson MT, Waite LR, Nindl G. Noninvasive treatment of inflammation using electromagnetic fields: current and emerging therapeutic potential. Biomed Sci Instrum 2004; 40: 469-474.

4. Żurawski P, Naskręcki R, Michalak M, et al. Pomiar parametrów pola elektromagnetycznego niskiej częstotliwości stosowanego w fizykoterapii. Fizjoter Pol 2007; 7: 45-51.

5. Chmara E, Cieślewicz A. Niefarmakologiczne metody leczenia bólu. Farm Współcz 2010; 3: 15-19.

6. Skalska-Izdebska R, Zwolińska J, Weres A, et al. Możliwości wykorzystania zmiennego pola magnetycznego w leczeniu schorzeń i urazów narządu ruchu. Zamojskie Studia i Materiały 2006; 8: 167-173.

7. Wang HY, Zhai LJ, Qian M. The internal energies of Heisenberg magnetic systems. J Magn Magn Mater 2014; 354: 309-316.

8. Kubisz L, Werner H, Świdziński T, et al. Pomiar parametrów zmiennego pola magnetycznego niskiej częstotliwości generowanego przez wybrany aparat do magnetoterapii. Now Lek 2010; 79: 199-203.

9. Samborski W. Niefarmakologiczne metody leczenia bólu w reumatologii. Przew Lek 2007; 3: 55-59.

10. Posłuszny M. Magnetoterapia - terapia naturalna wspomożona osiągnięciami technologii. Wprowadzenie do magnetoterapii. Artykuł sponsorowany. Prakt Fizjoter Rehabil 2015; 62: 17-20.

11. Posłuszny M. Magnetoterapia w leczeniu osób starszych. Prakt Fizjoter Rehabil 2015; 67: 59-62.

12. Gajewski M, Rzodkiewicz P, Maśliński S, et al. The role of physiological elements in future therapies of rheumatoid arthritis. III. The role of the electromagnetic field in regulation of redox potential and life cycle of inflammatory cells. Reumatologia 2015; 53: 219-224.

13. Genesan K, Gengadharan AC, Balachandran C, et al. Low frequency pulsed electromagnetic field- a viable alternative therapy for arthritis. Indian J Exp Biol 2009; 12: 939-948.

14. Cieślińska-Świder J. Przegląd metod fizykoterapeutycznych stosowanych $w$ reumatoidalnym zapaleniu stawów. Rehabil Prakt 2014; 4: 64-69.

15. Księżopolska-Orłowska K. Postępowanie rehabilitacyjne w reumatologii. Reumatologia 2012; 50: 181-184.

16. Gąsiorowski J, Sciepurko J. Magnetoterapia - bezpieczna alternatywa w walce z bólem. Prakt Fizjoter Rehabil 2014; 48: 32-33.

17. Żurawski P, Stryła W. Efekty biologiczne oddziaływania na człowieka pól elektromagnetycznych niskich częstotliwości. Probl Hig Epidemiol 2011; 92: 167-172.

18. Boyle P, Autier P, Bartelink $\mathrm{H}$, et al. Ionizing and non-ionizing radiation. In: European Code against cancer and scientific justifica- 
tion. Zatoński W. (ed). Medycyna Praktyczna: Centrum Onkologii - Instytut im. M. Skłodowskiej-Curie, Kraków 2007; 59-63.

19. Richmond SJ. Magnet therapy for the relief of pain and inflammation in rheumatoid arthritis (CAMBRA): A randomised placebo-controlled crossover trial. Trials 2008; 9: 53.

20. Zdrodowska B, Leszczyńska-Filus M, Leszczyński R, et al. Porównanie wpływu laseroterapii i magnetoterapii na poziom bólu oraz zakres ruchomości kręgosłupa osób z chorobą zwyrodnieniową dolnego odcinka kręgosłupa. Pol Merkuriusz Lek 2015; 38: 26-31.

21. Leśniewicz J, Pieszyński I, Zboralski K, et al. The effect of selected physical procedures on mobility in women with rheumatoid arthritis. Pol Merkuriusz Lek 2014; 37: 335-337.

22. Macfarlane GJ, Paudyal P, Doherty M, et al. A systematic review of evidence for the effectiveness of practitioner-based complementary and alternative therapies in the management of rheumatic diseases: rheumatoid arthritis. Rheumatology 2012; 51: 1707-1713.

23. Tederko P, Krasuski M. Oddziaływanie przeciwbólowe magnesów stałych- dowody na skuteczność. Fizjoter Pol 2011; 11: 289-301.

24. Grote A, Lackner H, Kelz C, et al. Short-term effects of pulsed electromagnetic fields after physical exercise are dependent on autonomic tone before exposure. Eur J Appl Physiol 2007; 101: 495-502.

25. ICNIRP Statement. Medical magnetic resonance (MR) procedures: protection of patients. Health Phys 2004; 87: 197-216.

26. Nasiłowska-Barud A, Żuk M. Wybrane problemy funkcjonowania psychicznego $u$ chorych $z$ przewlekłymi chorobami układowymi tkanki łącznej na przykładzie reumatoidalnego zapalenia stawów. Wiad Lek 2015; 68: 279-283.

27. Raciborski F, Kłak A, Kwiatkowska B. Indirect costs of rheumatoid arthritis. Reumatologia 2015; 53: 268-275.

28. Krawczyk-Wasielewska A, Kuncewicz E, Sobieska M, et al. Ocena skuteczności fizykoterapii w uśmierzaniu bólu towarzyszącego reumatoidalnemu zapaleniu stawów. Nowa Med 2007; 4: 74-79.

29. Migut N, Kwolek A, Zwolińska J. Wpływ postępowania rehabilitacyjnego na czynność ręki u kobiet z reumatoidalnym zapaleniem stawów. Zamojskie Studia i Materiały 2013; 15: 21-32.

30. Steczko D, Bijak E, Bijak P, et al. Postępowanie rehabilitacyjne w reumatoidalnym zapaleniu stawów. Prakt Fizjoter Rehabil 2013; 45: 45-52.

31. Drużbicki M, Zwolińska J, Przysada G, et al. Assessment of hand mobility in patients with rheumatoid arthritis using a computer measurement station. Reumatologia 2013; 51: 133-138.

32. Rojczyk-Chmarek J, Błaszczyk J, Gieremek K, et al. Biomechaniczne aspekty czynności stawu tokciowego w reumatoidalnym zapaleniu stawów. Fizjoter Pol 2014; 14: 6-16.

33. Krawczyk-Wasielewska A, Kuncewicz E, Sobieska M, et al. Ocena stanu funkcjonalnego chorych na reumatoidalne zapalenie stawów przed i po zastosowaniu fizykoterapii. Chir Narz Ruchu 2009; 74: 361-366.

34. Prusinowska A, Maciejewski W, Turski P, et al. Paluch koślawy w stopie reumatycznej - leczenie operacyjne i rehabilitacja. Reumatologia 2011; 49: 90-95.

35. Szczegielniak J, Łuniewski J, Bogacz K, et al. Zastosowanie metody Kinesiology Taping w fizjoterapii ręki reumatoidalnej badanie pilotażowe. Ortop Traumatol Rehab 2012; 14: 23-30.

36. Pacholec A, Księżopolska-Orłowska K, Jędryka-Góral A, et al. Współczesne kierunki rehabilitacji w zapalnych chorobach narządu ruchu. Reumatologia 2013; 51: 298-303.
37. Smoleńska Ż, Zdrojewski Z. Metabolomics and its potential in diagnosis, prognosis and treatment of rheumatic diseases. Reumatologia 2015; 53: 152-156.

38. Bączyk G, Klijewska M. Wpływ rehabilitacji na funkcjonowanie i jakość życia chorych z reumatoidalnym zapaleniem stawów. Now Lek 2005; 74: 123-126.

39. Kalmus P, Pracka D, Pracki T, et al. Ocena skuteczności stałego, naprzemiennego pola magnetycznego $w$ wybranych aspektach terapii pacjentów z chorobami reumatologicznymi. Acta Balneol 2010; 52: 84-89.

40. Kądziołka J, Grzegorczyk J, Rawska A. Wpływ fizjoterapii na poziom odczuwanego bólu u chorych na reumatoidalne zapalenie stawów. Prz Med Uniw Rzesz 2009; 7: 46-54.

41. Kumar VS, Kumar DA, Kalaivani K, et al. Optimization of pulsed electromagnetic field therapy for management of arthritis in rats. Bioelectromagnetics 2005; 26: 431-439.

42. Dortch $A B$, Johnson MT. Characterization of pulsed magnetic field therapy in a rat model for rheumatoid arthritis. Biomed Sci Instrum 2006; 42: 302-307.

43. Shupak NM, McKay JC, Nielson WR, et al. Exposure to a specific pulsed low-frequency magnetic field: a double-blind placebo-controlled study of effects on pain ratings in rheumatoid arthritis and fibromyalgia patients. Pain Res Manag 2006; 11: 85-90.

44. Greaves CJ, Harlow TN. Exploration of the validity of weak magnets as a suitable placebo in trials of magnetic therapy. Complement Ther Med 2008; 16: 177-180.

45. Skalska-Izdebska R, Fatyga P, Szczypiorowska-Goraj B, et al. Ocena skuteczności fizykoterapii w leczeniu reumatoidalnego zapalenia stawów. Young Sport Science of Ukraine 2012; 5: 205-215.

46. Walasik M, Gałęcki S, Dudkiewicz Z. Efektywność wybranych zabiegów fizjoterapeutycznych w obrębie ręki, u pacjentów z reumatoidalnym zapaleniem stawów (RZS), leczonych w warunkach ambulatoryjnych - wybrane aspekty. Kwart Ortop 2013; 2: 194-204.

47. Chwieśko-Minarowska S, Kuryliszyn-Moskal A, Pijanowska M, et al. The comparison of multi-waved locked system laser and low-frequency magnetic field therapy on hand function and quality of life in patients with rheumatoid arthritis - preliminary study. Acta Balneol 2014; 56: 181-184.

48. Eccles NK. A critical review of randomized controlled trials of static magnets for pain relief. J Altern Complem Med 2005; 13: 495-509.

49. Kuncewicz E, Samborski P, Szpera A, et al. The Polish model of physiotherapeutic conduct in rheumatoid arthritis and recommendation of Ottawa Panel. Chir Narz Ruchu 2009; 74: 289-294.

50. Posłuszny M, Mrozowiak M. Spór o działanie pola magnetycznego. Czy naprawdę nie ma żadnych przeciwwskazań? Prakt Fizjoter Rehabil 2015; 66: 38-40.

51. Biundo MD, Joseph J, Rush MD, et al. Rehabilitation of patients with rheumatic diseases. In: Kelley's Textbook of Rheumatology. Harris ED, Sledge CB, Budd RC, et al. (eds.) $7^{\text {th }}$ ed. Elsevier Saunders, Philadelphia 2005; 826-838.

52. Hurkmans EJ, van der Giesen FJ, Bloo H. Physiotherapy in rheumatoid arthritis: development of a practice guideline. Acta Reumatol Port 2011; 36: 146-158.

53. Spodaryk K, Bromboszcz J. Fizykoterapia - potrzeba badań naukowych. Rehabil Med 2004; 8: 98-114. 